\title{
Treatment of euvolemic hyponatremia in the intensive care unit by urea
}

Guy Decaux ${ }^{1 *}$, Caroline Andres ${ }^{1}$, Fabrice Gankam Kengne ${ }^{1}$, Alain Soupart ${ }^{1,2}$

\begin{abstract}
Introduction: Hyponatremia in the intensive care unit (ICU) is most commonly related to inappropriate secretion of antidiuretic hormone (SIADH). Fluid restriction is difficult to apply in these patients. We wanted to report the treatment of hyponatremia with urea in these patients.

Methods: Two groups of patients are reported. The first one is represented by a retrospective study of 50 consecutive patients with mild hyponatremia treated with urea. The second group is presented by a series of 35 consecutive patients with severe hyponatremia acquired outside the hospital ( $\leq 115 \mathrm{mEq} / \mathrm{L}$ ) who where treated by isotonic saline and urea ( 0.5 to $1 \mathrm{~g} / \mathrm{kg} /$ day), administered usually by gastric tube.

Results: In the first group with mild hyponatremia (128 $\pm 4 \mathrm{mEq} / \mathrm{L})$ the serum sodium (SNa) increased to a mean value of $135 \pm 4 \mathrm{mEq} / \mathrm{L}(P<0.001)$ after two days of urea therapy $(46 \pm 25 \mathrm{~g} /$ day $)$, despite a large fluid intake $(>2$ L/day). The mean duration of urea therapy was six days (from 2 to 42 days). Six patients developed hyponatremia again once the urea was stopped, which necessitated its reintroduction. Six patients developed hypernatremia (maximum value $155 \mathrm{mEq} / \mathrm{L}$ ). In the second group, SNa increased from $111 \pm 3 \mathrm{mEq} / \mathrm{L}$ to $122 \pm 4 \mathrm{mEq} / \mathrm{L}$ in one day $(P<0.001)$. All the patients with neurological symptoms made a rapid recovery. No side effects were observed.
\end{abstract}

Conclusions: These data show that urea is a simple and inexpensive therapy to treat euvolemic hyponatremia in the ICU.

\section{Introduction}

In the intensive care unit, hyponatremia occurs frequently and is associated with an increased mortality [1-4]. It is mostly related to the presence of inappropriate antidiuresis due to an excess of ADH. Management of this condition usually implies water restriction. This is of poor applicability in patients requiring multiple intravenous medications and/or nutritional support. Recently a new class of drugs antagonizing the V2 receptor (V2RA) has been developed: the vaptans [5-9].

Two of them are already available on the market: Conivaptan for the intravenous route [10-16] and Tolvaptan for the oral route [17]. The present data recall that urea is an effective and easy therapeutic choice to correct hyponatremia related to SIADH [18-21] with special attention for patients in the intensive care unit.

\footnotetext{
* Correspondence: guy.decaux@skynet.be

${ }^{1}$ Research Unit on Hydromineral Metabolism, Department of General Internal Medicine, University Erasme Hospital, ULB, Route de Lennik 808, Brussels, B-1070, Belgium

Full list of author information is available at the end of the article
}

The main criticism to the use of urea orally is its taste; this is not a problem in the intensive care unit as it is usually administered by gastric tube or intravenously. No prospective data comparing V2 antagonists to urea are available. We present a large retrospective series of patients with moderate or severe hyponatremia treated with urea and shows that its use is a easy, save and inexpensive treatment.

\section{Materials and methods}

Study I - Moderate hyponatremia (120 to $134 \mathrm{mmol} / \mathrm{L}$ )

We analyzed the charts of 50 consecutive patients treated with urea in the intensive care unit.

Some serum parameters two days before and the first two days during urea therapy are presented (Figure 1). In 10 patients, urine parameters and balance data were also available (see Table 1). All the patients were receiving isotonic or half isotonic saline solutions before urea administration.

Pharmaceutical grade urea (medicinal urea, Certa ${ }^{\circ}$, Braine l'Alleud, Belgium) is usually prepared by the 


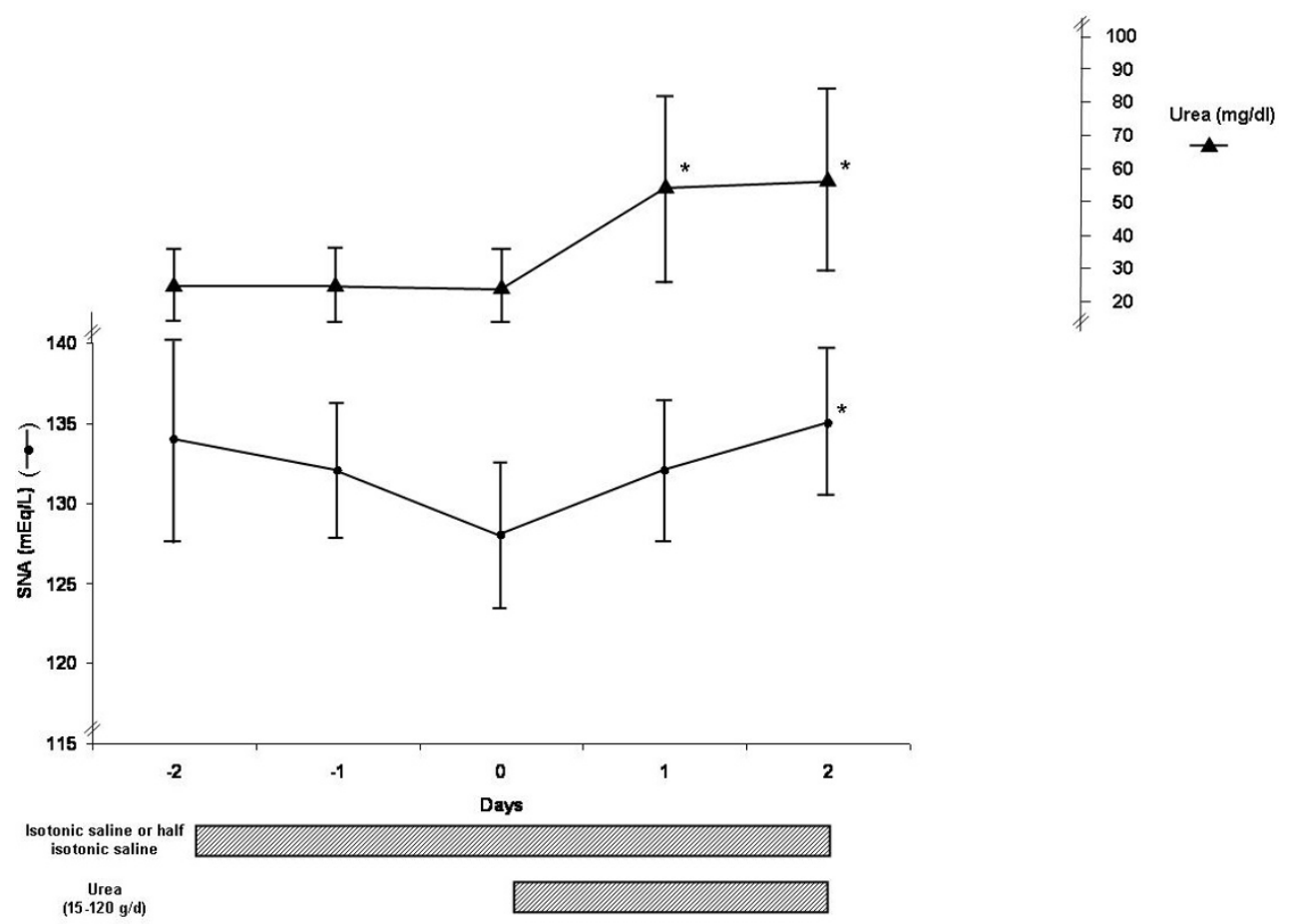

Figure 1 Evolution of SNa and blood urea in $\mathbf{5 0}$ patients before and after urea therapy.

pharmacy in bags of 15 or $30 \mathrm{~g}$ [22], which are dissolved in $100 \mathrm{ml}$ water and given by gastric tube over 5 to 10 minutes (except in case of brain haemorrhage in which urea is given continuously). In some patients urea is directly dissolved in the liquid nutritional support. Patients taking it orally dissolved urea in orange juice (or syrup) and take it after the meal.

\section{Study II - Severe hyponatremia ( $\leq 115 \mathrm{mmol} / \mathrm{L}$ )}

We analyzed the records of 35 consecutive patients with severe hyponatremia treated with urea (Figure 2a).
In 12 of these patients urea was added $24 \mathrm{hr}$ after 1 or $2 \mathrm{~L}$ isotonic saline (Figure $2 \mathrm{~b}$ ).

In 10 patients, $\mathrm{SNa}$ and $\mathrm{S}$ urea were measured before and every $4 \mathrm{hr}$ after urea $(0.5 \mathrm{~g} / \mathrm{kg} / 12 \mathrm{~h})$ administration combined with perfusion of $1 \mathrm{~L}$ isotonic saline each $12 \mathrm{hr}$ (Figure 2c).

In all the patients $\mathrm{SNa}$ was measured at least two times (a few hours to 24 hrs before urea therapy).

For Studies I and II, an ethical approval was obtained. Data are provided as mean $\pm \mathrm{SD}$, we use the one-way analysis of variance and the Tukey-Kramer multiple comparisons test.

Table 1 Evolution of some blood and urine parameters in 10 patients with mild hyponatremia treated by $45 \mathrm{~g}$ urea/ daily at least during three days

\begin{tabular}{lcccc}
\hline & Day -1 & Day 0 & Day 1 & Day 2 \\
\hline S Urea $(\mathrm{mg} / \mathrm{dL}) \mathrm{N}<40$ & $25( \pm 10.1)$ & $25( \pm 9.5)$ & $60( \pm 25.9)^{*}$ & $67 \pm 29.7^{*}$ \\
S Creat $(\mathrm{mg} / \mathrm{dL}) \mathrm{N}<1.1$ & $0.5( \pm 0.1)$ & $0.5( \pm 0.1)$ & $0.5( \pm 0.1)$ & $0.5( \pm 0.1)$ \\
S Na (mmol/L) & $133( \pm 1.3)$ & $130( \pm 1.8)$ & $132( \pm 3.7)$ & $136( \pm 5.0)^{*}$ \\
S K (mmol/L) & $4( \pm 0.4)$ & $4( \pm 0.3)$ & $4( \pm 0.3)$ & $4( \pm 0.3)$ \\
U Osm (mosmol/kg) & $587( \pm 153.3)$ & $623( \pm 136.5)$ & $637( \pm 112.2)$ & $690( \pm 122.0)$ \\
U Urea $(\mathrm{mg} / \mathrm{dL})$ & $938( \pm 511.4)$ & $1031( \pm 476.8)$ & $1806( \pm 461.6)^{*}$ & $2187( \pm 534.1)^{*}$ \\
U Creat $(\mathrm{mg} / \mathrm{dL})$ & $44 \pm 25.5)$ & $45( \pm 23.0)$ & $30( \pm 15.0)$ & $29( \pm 16.3)$ \\
U Na $(\mathrm{mmol} / \mathrm{L})$ & $127( \pm 32.9)$ & $139( \pm 43.2)$ & $112( \pm 44.0)$ & $93( \pm 39.0)$ \\
FE.Na $(\%) \mathrm{N}<1.5 \%$ & $1.2( \pm 0.6)$ & $1.2( \pm 0.5)$ & $1.51( \pm 0.9)$ & $1.31( \pm 0.6)$ \\
FE.Osm $(\%) \mathrm{N}<3 \%$ & $2.38( \pm 0.6)$ & $2.45( \pm 0.5)$ & $3.99( \pm 1.8)^{*}$ & $4.62( \pm 1.6)^{*}$ \\
\hline
\end{tabular}

${ }^{*} P<0.01$ compared to day 0 .

$\mathrm{S}$, serum; U, urine; FE.Na, fractional sodium excretion; FE.Osm, fractional osmolytes excretion.

To convert $\mathrm{S}$ urea $(\mathrm{mg} / \mathrm{dl})$ in BUN $(\mathrm{mg} / \mathrm{dl})$ multiplied by 0.467 . 


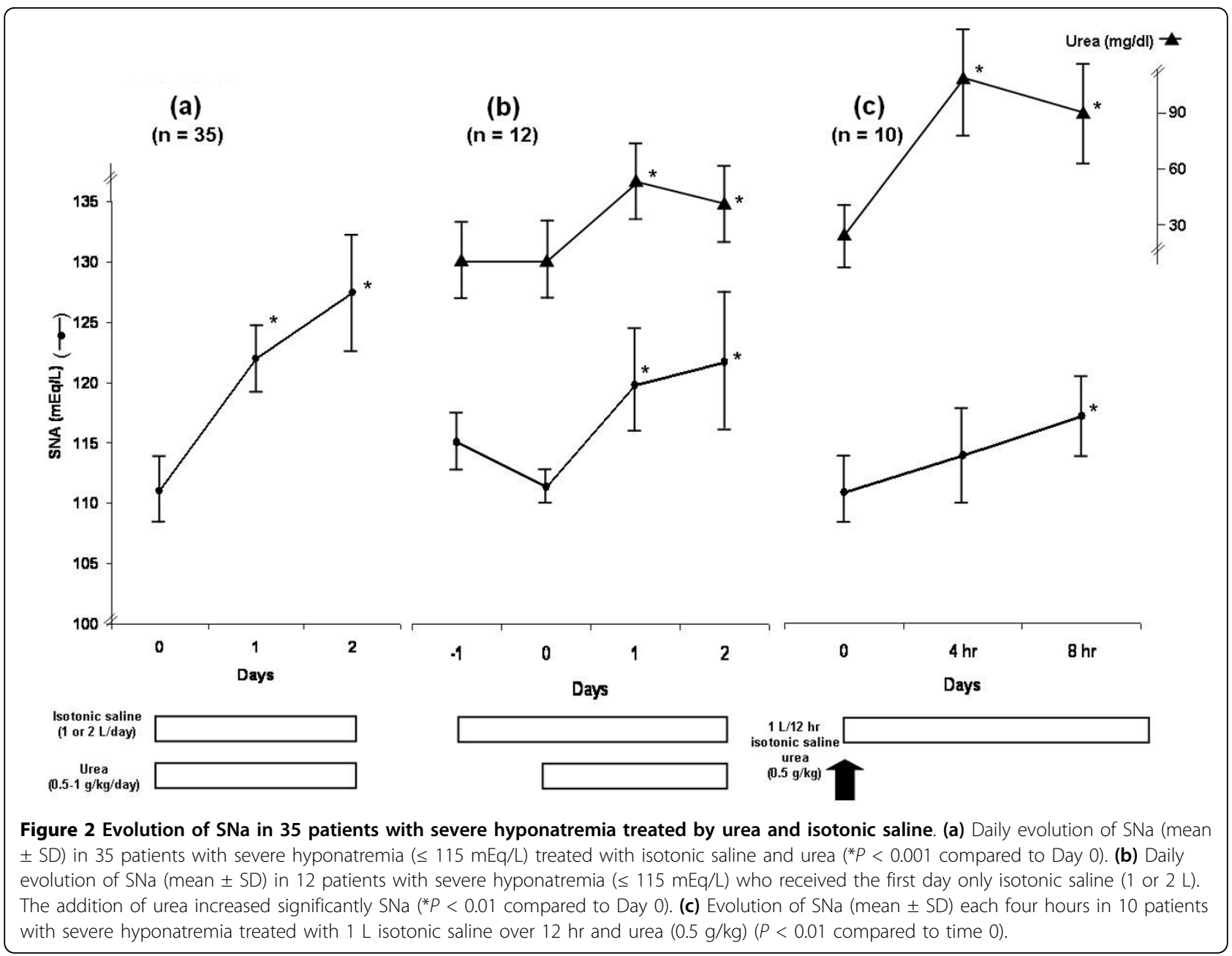

\section{Results}

\section{Moderate hyponatremia}

Figure 1 presents the evolution of $\mathrm{SNa}$ and S.urea in 50 patients treated by urea for mild hyponatremia developed it in the intensive care unit (mean age: $71 \pm 20$ years). Two-thirds of the patients were receiving isotonic saline ( 1 or $2 \mathrm{~L} /$ day) and one-third received half isotonic saline ( 1 or $2 \mathrm{~L}$ ) during the two days before and after urea administration. It is usual in our intensive care unit that when infusion induced or aggravated hyponatremia to add urea, while maintaining the same volume of liquid administration (liquid nutritional support, medication, and so on).

$\mathrm{SNa}$ increased significantly in all the patients $(\triangle \mathrm{SNa}$ in two days: $7 \pm 4 \mathrm{mEq} / \mathrm{L} ; P<0.001)$ ). The dose of urea varied between 15 and $120 \mathrm{~g} /$ day given usually by gastric tube in one to four doses. The mean dose was $46 \pm 25$ $\mathrm{g} /$ day. Ten patients received $15 \mathrm{~g} /$ day, 10 received $30 \mathrm{~g} /$ day, 11 received $45 \mathrm{~g}$ (usually $3 \times 15 \mathrm{~g} /$ day), 14 received $60 \mathrm{~g} /$ day, 3 received $90 \mathrm{~g} /$ day and 2 received $120 \mathrm{~g} /$ day.
Urea was given by gastric tube in $80 \%$ of the patients and by mouth in $20 \%$.

Table 1 presents the evolution of some blood and urine parameters in 10 patients where these data were available; all these patients received at least $45 \mathrm{~g} /$ day urea during three days. Table 1 shows that in these patients the intake of urea was associated, as expected, with an increase in urine urea concentration (while urine osmolality remained high). In those patients, total liquid input the first day of urea therapy was estimated at $3.031 \pm 1.244 \mathrm{~mL}$ and output was $3,905 \pm 1,016 \mathrm{~mL}$ (mean difference $874 \mathrm{~mL})(P<0.01)$ which contribute to the increase in $\mathrm{SNa}$ despite the high fluid intake.

The origin of SIADH was due to different brain diseases (tumour, subdural hematoma, subarachnoid haemorrhage, brain hematoma, posttraumatic brain injury, meningitis, and so on) in $80 \%$ of the patients and in $20 \%$ vs non brain diseases (neoplasms, pneumonia, COPD, and so on). Seven patients developed hypernatremia during urea therapy (maximum value of SNa $155 \mathrm{mEq} / \mathrm{L}$ ). 
The dose of urea was adjusted by the intensivists depending of the increase in SNa.

Mean duration of treatment was six days (from 2 to 42 days in the ICU). Hyponatremia recurred in six patients when urea was stopped, which necessitated its reintroduction.

\section{Severe hyponatremia}

Figure 2a presents the evolution of SNa in 35 patients with severe hyponatremia which was acquired outside the hospitals (in 10 patients it was due to thiazides, in 8 to neoplasic diseases, and so on). Most patients presented neurological symptoms (four were asymptomatic, four were comatose, three presented seizures, all the other were described as confused or somnolent). $\mathrm{SNa}$ increased from $111 \pm 3 \mathrm{mEq} / \mathrm{L}$ to $122 \pm 4 \mathrm{mEq} / \mathrm{L}$ in one day $(P<0.001)$ and all the patients with neurological symptoms made a rapid recovery.

$\mathrm{SNa}$ increased more than $12 \mathrm{mmol} / \mathrm{L}$ the first day in 12 patients and in 13 patients the increase in $\mathrm{SNa}$ was higher than $18 \mathrm{mmol} / \mathrm{L} / 48 \mathrm{hr}$. In two of these patients the intensivist lowered the $\mathrm{SNa}$ again by giving desmopressin (DDAVP) and water. No cases of clinical osmotic demyelination syndrome (ODS) developed. When high doses of urea are used ( $\geq 60 \mathrm{~g} /$ day) it is usual to avoid the next dose of urea if blood urea level is higher than $150 \mathrm{mg} / \mathrm{dL}$ (SNa and urea are measured in most patients every 8 to $12 \mathrm{hr}$ when large doses are used). No cases of hypernatremia were observed. The 10 patients with thiazides induced hyponatremia presented biological data similar to patients with SIADH (low urea and uric acid levels) [23,24]; it is likely that isotonic saline alone was sufficient in most of these patients.

Seven patients presented hypokaliemia (range 2.3 to $3.4 \mathrm{mmol}$, four were taking diuretics).

All the patients presented with a systolic blood pressure over $100 \mathrm{mmHg}$ and showed no signs of overt hypovolemia (clinically or biologically).

In 12 patients (Figure 2b) urea therapy was initiated after 1 or $2 \mathrm{~L}$ isotonic saline (given over one day) and which did not improved natremia (two were on thiazide).

In 10 patients (Figure 2c), $1 \mathrm{~L}$ isotonic saline was administered each $12 \mathrm{hr}$ with $0.5 \mathrm{~g} / \mathrm{kg}$ of urea (given by mouth or gastric tube). In these patients, mean $\mathrm{SNa}$ increased by $7 \pm 4 \mathrm{mmol} / \mathrm{L}$ in eight hours (range 1 to $11 \mathrm{mmol} / \mathrm{L} ; P<0.01$ ). Urea increased from $27 \pm 14 \mathrm{mg} /$ $\mathrm{dL}$ to $96 \pm 30 \mathrm{mg} / \mathrm{dL}$ four hours after urea administration $(P<0.001)$.

\section{Discussion}

Our data show that urea is an efficient and safe method to manage hyponatremia in the intensive care unit. Urea has been used orally or intravenously over time as an osmotic diuretic drug and as an agent to reduce intracranial and intraocular pressure [25]. As opposed to mannitol, urea enters intracellular spaces rapidly (in less than one hour) throughout the body, decreasing the immediate risk of sudden cardiac decompensation due to rapid intravascular volume expansion and does not induce a transient decrease in $\mathrm{SNa}$ as observed with mannitol (translocation hyponatremia) [26]. However, because urea penetrates into the CNS only about onetenth as quickly as into muscle, a significant intravascular to CNS urea gradient occurs (during 4 to $10 \mathrm{hrs}$ ) [27]. Decreases in brain water content and intracranial pressure during urea administration have been measured experimentally and/or clinically [25].

In this study, urea was not used to treat eventual brain oedema due to hyponatremia $[28,29]$.

High doses of urea can be given on a long-term basis without renal toxicity which is not the case for mannitol. In individuals with previously normal baseline renal function, the mean total dose of mannitol that precipitated acute renal failure was $626 \pm 270 \mathrm{~g}$ over two to five days [30] (which represents about $209 \mathrm{~g} \pm 90 \mathrm{~g}$ urea on an equimolar basis).

Many patients presented hyponatremia associated with various brain diseases, it is likely that most presented SIADH as isotonic saline infusion (2/3 of the patients) or half-isotonic saline (1/3 of the patients) was not able to correct $\mathrm{SNa}$ [31], while the introduction of urea corrected $\mathrm{SNa}$ (Figures 1 and $2 \mathrm{~b}$ ).

The mean increase in $\mathrm{SNa}$ was around $4 \mathrm{mmol} / \mathrm{L}$ the first day of urea administration and $7 \mathrm{mmol} / \mathrm{L}$ in $48 \mathrm{hrs}$ in the patients with mild hyponatremia, these results are similar to those reported with conivaptan whether used orally or intravenously [10-16]. In our study there was no fluid restriction, while in the conivaptan studies fluid intake was less than $2 \mathrm{~L} /$ day. Conivaptan is a substrate and potent inhibitor of the microsomal enzyme cytochrome P450 (CYP) 3A4, the concomitant use of several agents are prohibited, including chemotherapeutic agents, calcium channel blockers, 3-hydroxy-3 methylglutaryl-coenzyme A reductase inhibitors, benzodiazepines, and immunosuppressants. Use of conivaptan has been allowed for four-days treatment and by the intravenously route. Another anti V2 medication need to be used for patients with persistent SIADH (which is frequent) while urea has no long-term toxicity $[25,32,33]$ and can also be used intravenously, although in the present study the 85 patients with hyponatremia were all treated orally (less expensive than the intravenous route; for example Ureaphil where each bottle of $135 \mathrm{~mL}$ contains $40 \mathrm{~g}$ urea which need to be dissolved in 5\% dextrose) $[19,22]$. In the large SALT trials with Tolvaptan, patients had free access to water but first day of treatment $\mathrm{SNa}$ increases of about 2 to $3 \mathrm{mmol} / \mathrm{L}$ and about 
$7 \mathrm{mmol} / \mathrm{L}$ at the end of the study on Day 30 [17]. We did not include in this study patients with symptomatic acute hyponatremia (mainly postoperative). All our patients with severe hyponatremia developed it outside the hospital and are considered as at least partially, chronically hyponatremia ( $>48 \mathrm{hr}$ ) and no patients presented with primary polydipsia.

In this series of severe hyponatremic patients, only four were frankly comatose but the majority were symptomatic and were treated by isotonic saline combined with urea given orally (by gastric tube if needed). In our hospital severe euvolemic hyponatremia is usually treated with a combination of urea and isotonic saline which is an alternative to hypertonic saline [21]. At the present time, severe symptomatic hyponatremia particularly if epileptic seizures are present should be treated with hypertonic saline (consensus conference) [34]. Hypertonic saline will increase $\mathrm{SNa}$ theoretically more rapidly than urea.

Establishment of a depletional origin of hyponatremia is not always easy particularly in the medical ward $[35,36]$. The combined treatment of isotonic saline and urea has some advantages. If there is some salt depletion, isotonic saline will be useful while if excess water is the main factor of hyponatremia, urea will be useful (by subtracting water).

Although we discourage an increase of $\mathrm{SNa}$ of more than $10 \mathrm{mmol} / \mathrm{L} /$ day, many patients presented a too large increase $[21,22,34]$. We know that urea has a protective effect against osmotic demyelination syndrome (ODS) in animals [37-40]. SNa was decreased again only in two patients by giving DDAVP and water [41-44]. No clinically cases of ODS were observed in our patients, this could reflect the protective effect of urea.

In all the studies published with the vaptans, no patients with $\mathrm{SNa}$ less than $115 \mathrm{mEq} / \mathrm{L}$ where included. Despite the attractiveness of using a pure aquaretic agent to correct life-threatening hyponatremia, insufficient data are available from clinical trials to know if sufficiently rapid correction can be achieved in patients with acute, severe hyponatremia without the use of hypertonic saline. Indeed, present studies show that V2RA diuresis does not begin to increase before one to two hours.

Urea in large doses $(1 \mathrm{~g} / \mathrm{kg})$, when administered rapidly by gastric tube in a matter of minutes, has a purgative effect which creates troublesome nursing problems in the comatose patients. This effect could be avoided by administering the urea over a long period of time, or by fractioning the dose. In our study, this was never a problem; no tracheal aspiration was reported, but we avoided giving urea rapidly in large amounts. We also administered urea continuously (for example in the liquid nutritional support) in patients with brain haemorrhage, to avoid any brain shrinkage. As previously mentioned, urea was not used to treat brain oedema in this study (although this could represent a good indication, particularly if the intravenous route is used) [21]. We can expect that acute administration of urea at $0.5 \mathrm{gr} / \mathrm{kgBW}$ intravenously over one hour or orally will rapidly (one hour) increase serum osmolality by $15 \mathrm{mOsm} / \mathrm{kg} / \mathrm{H}_{2} \mathrm{O}$ during a few hours (renal elimination).

These data report the use of urea in an intensive care unit, but urea can also be used to treat many patients over the long-term (years) without problems and likely with similar efficacy than the V2 antagonists but at a much lower price [45]. In many patients, taste is not a complaint, particularly if low doses are sufficient to control hyponatremia (15 to $30 \mathrm{~g} /$ day).

\section{Conclusions}

These data emphasise that urea combined with isotonic saline is an easy way to treat euvolemic hyponatremia in the ICU.

A prospective treatment comparing this old treatment with the V2RA needs to be done.

\section{Key messages}

- In the intensive care unit, urea combined with isotonic saline is an easy and inexpensive way to treat euvolemic hyponatremia.

\section{Abbreviations}

DDAVP: desmopressin; FE.Na: fractional excretion of sodium (in \%); FE.osm: fractional excretion of osmoles (in \%); ODS: osmotic demyelination syndrome; SIADH: syndrome of inappropriate secretion of $\mathrm{ADH}$; $\mathrm{SNa}$ : serum sodium; V2RA: V2 receptor antagonist.

\section{Acknowledgements}

We are indebted to Serge Brimouille for helpful discussions. This study was supported by a grant from the Fonds National de la Recherche Scientifique (FNRS), convention n³.4656.09.

\section{Author details}

${ }^{1}$ Research Unit on Hydromineral Metabolism, Department of General Internal Medicine, University Erasme Hospital, ULB, Route de Lennik 808, Brussels, B-1070, Belgium. '2Department of Internal Medicine, Tubize-Jolimont Hospital, Avenue de Scandiano 8, Tubize, B-1480, Belgium.

\section{Authors' contributions}

All the authors contributed to the collection and analyse of the data in a similar way. All authors read and approved the final manuscript.

\section{Competing interests}

The authors declare that they have no competing interests.

Received: 23 February 2010 Revised: 25 May 2010

Accepted: 14 October 2010 Published: 14 October 2010

\section{References}

1. Palmer BF: Hyponatremia in the intensive care unit. Semin Nephrol 2009, 29:257-270.

2. De Vita MV, Gardenswartz MH, Konecky A, Zabetakis PM: Incidence and etiology of hyponatremia in an intensive care unit. Clin Nephrol 1990, 34:163-166. 
3. Stelfox MT, Ahmed SB, Khandwala F, Zygun D, Shahpori R, Lauplan K: The epidemiology of intensive care unit-acquired hyponatremia and hypernatremia in medical-surgical intensice care units. Crit Care 2008, 12: R162.

4. Wald R, Jaber BL, Price LL, Upadhyay A, Madias NE: Impact of hospitalassociated hyponatremia on selected outcomes. Arch Intern Med 2010, 170:294-302.

5. Gross P, Marczewski T, Herbrig K: The vaptans ante portas: a status report. Nephrol Dial Transplant 2009, 24:1371-1373.

6. Chen S, Jalandhara N, Battle D: Evaluation and management of hyponatremia: an emerging role for vasopressin receptor antagonists. Nat Clin Pract Nephrol 2007, 3:82-95.

7. Quitbnat F, Gross P: Vaptans and the treatment of water-retaining disorders. Semin Nephrol 2006, 26:234-243.

8. Greenberg A, Verbalis JG: Vasopressin receptor antagonists. Kidney Int 2006, 69:2124-2130.

9. Decaux G, Soupart A, Vassart G: Non-peptide arginine-vasopressin antagonists: the vaptans. Lancet 2008, 371:1624-1632.

10. Ghali JK, Koren MJ, Tayor JR, Brooks-Asplund E, Fan K, Long WA, Smith N: Efficacy and safety of oral conivaptan: a V1A/V2 vasopressin receptor antagonist, assessed in a randomized, placebo-controlled trial in patiens with euvolemic or hypervolemic hyponatremia. J Clin Endocrinol Metab 2006, 91:2145-2152.

11. Decaux G: Long-term treatment of patients with inappropriate secretion of antidiuretic hormone by the vasopressin receptor antagonist conivaptan, urea, or furosemide. Am J Med 2001, 110:582-584.

12. Zeltser D, Rosansky S, van Rensburg H, Verbalis JG, Smith N, Conivaptan Study Group: Assessment of the efficacy and safety of intravenous conivaptan in euvolemic and hypervolemic hyponatremia. Am J Nephrol 2007, 27:447-457.

13. Verbalis JG, Zeltser D, Smith N, Barve A, Andoh M: Assessment of the efficacy and safety of intravenous conivaptan in patients with euvolaemic hyponatremia: subgroup analysis of a randomized, controlled study. Clin Endocrinol (Oxf) 2008, 69:159-168.

14. Ananne D, Decaux G, Smith N, Conivaptan Study Group: Efficacy and safety of oral conivaptan, a vasopressin-receptor antagonist, evaluated in a randomized, controlled trial in patients with euvolemic or hypervolemic hyponatremia. Am J Med Sci 2009, 337:28-36.

15. Murphy T, Dhar R, Diringer M: Conivaptan bolus dosing for the correction of hyponatremia in the neurointensive care unit. Neurocrit Care 2009, 11:14-19.

16. Velez JC, Dopson SJ, Sanders DS, Delay TA, Arthur JM: Intravenous conivaptan for the treatment of hyponatremia caused by the syndrome of inappropriate secretion of antidiuretic hormone in hospitalized patients: a single-centre experience. Nephrol Dial Transplant 2010, 25:1524-1531.

17. Schrier RW, Gross P, Gheorghiade M, Berl T, Verbalis JG, Czerwiec FS, Orlandi C, Salt Investigators: Tolvaptan, a selective oral vasopressin V2receptor antagonist, for hyponatremia. N Engl J Med 2006, 355:2099-2112.

18. Decaux G, Brimioulle $S$, Genette F, Mockel J: Treatment of the syndrome of inappropriate secretion of antidiuretic hormone by urea. Am J Med 1980, 69:99-106.

19. Decaux G, Unger J, Brimioulle S, Mockel J: Hyponatremia in the syndrome of inappropriate secretion of antidiuretic hormone. Rapid correction with urea, sodium chloride, and water restriction therapy. JAMA 1982, 247:471-474.

20. Decaux $G$, Genette $F$ : Urea for long-term treatment of the syndrome of inappropriate secretion of antidiuretic hormone. Br Med I (Clin Res Ed) 1981, 283:1081-1083.

21. Decaux G, Soupart A: Treatment of symptomatic hyponatremia. Am J Med Sci 2003, 326:25-30.

22. Decaux $G$, Musch $W$, Soupart $A$ : Hyponatremia in the intensive care: from diagnosis to treatment. Acta Clinica Belgica 2000, 55:68-78.

23. Decaux $G$, Schlesser M, Coffernils M, Prospert F, Namias B, Brimioulle $S$, Soupart A: Uric acid, anion gap and urea concentration in the diagnosis approach to hyponatremic patients. Clin Nephrol 1994, 42:102-108.

24. Fenske W, Stork S, Koschker AC, Blechschmidt A, Lorenz D, Wortmann S, Allolio B: Value of fractional uric acid excretion in differential diagnosis of hyponatremic patients on diuretics. J Clin Endocrinol Metab 2008, 93:2991-2997.
25. Javid M: Urea - new use of an old agent. Reduction of intracranial and intraocular pressure. Surg Clin North Am 1958, 38:907-928.

26. Buckell M: Blood changes on intravenous administration of mannitol or urea for reduction of intracranial pressure in neurosurgical patients. Clin Sci 1964, 27:223-227.

27. Kleeman $\mathrm{CR}$, Daison $\mathrm{H}$, Levin E: Urea transport in the central nervous system. Am J Physiol 1962, 203:739-747.

28. Decaux G, Szyper M, Grivegnée A: Cerebral ventricular volume during hyponatremia. J Neurol Neurosurg Psychiatry 1983, 46:443-445.

29. Porzio P, Halberthal M, Bohn D, Halperin ML: Treatment of acute hyponatremia: ensuring the excretion of a predictable amount of electrolyte-free water. Crit Care Med 2000, 28:1905-1910.

30. Dorman HR, Sondheiner $J H$, Cadnapahornchai P: Mannitol induced acute renal failure. Medicine (Baltimore) 1990, 69:153-159.

31. Musch W, Decaux G: Treating the syndrome of inappropriate secretion of ADH with isotonic saline. QJM 1998, 91:749-753.

32. Verhoeven A, Musch W, Decaux G: Treatment of the polydipsiahyponatremia syndrome with urea. J Clin Psychiatry 2005, 66:1372-1375.

33. Kawai N, Ishikawa K, Nemoto K, Katano T, Takahashi S, Hori T, Asada T: Oral urea treatment for polydipsia-hyponatremia syndrome in patients with schizophrenia. J Clin Psychopharmacol 2009, 29:499-501.

34. Verbalis JG, Goldsmith SR, Greenberg A, Schrier RW, Sterns RH: Hyponatremia treatment guidelines 2007: expert panel recommendations. Am J Med 2007, 120:S1-S21.

35. Decaux G, Musch W: Clinical laboratory evaluation of the syndrome of inappropriate secretion of antidiuretic hormone. Clin J Am Soc Nephrol 2008, 3:1175-1184.

36. Musch W, Thimpont J, Vandervelde D, Vanhaeverbeke I, Berghmans T, Decaux G: Combined fractional excretion of sodium and urea better predicts response to saline in hyponatremia than do usual clinical and biochemical parameters. Am J Med 1995, 99:348-355.

37. Soupart A, Stenuit A, Perier O, Decaux G: Limits of brain tolerance to daily increments in serum sodium in chronically hyponatremic rats treated by hypertonic saline or urea. Clin Sci (Lond) 1991, 80:77-84.

38. Soupart A, Penninckx R, Stenuit A, Decaux G: Azotemia (48 h) decreases the risk of brain damage in rats after correction of chronic hyponatremia. Brain Res 2000, 852:167-172.

39. Soupart A, Silver S, Schroeder B, Sterns R, Decaux G: Rapid (24-hour) reaccumulation of brain organic osmolytes (particularly myo-Inositol) in azotemic rats after correction of chronic hyponatremia. J Am Soc Nephrol 2002, 13:1433-1441.

40. Soupart A, Schroeder B, Decaux G: Treatment of hyponatremia by urea decreases risks of brain complications in rats, a brain osmolyte contents analyses. Nephrol Dial Transplant 2007, 22:1856-1863.

41. Soupart A, Penninckx R, Crenier L, Stenuit A, Perier O, Decaux G: Prevention of brain demyelination in rats after excessive correction of chronic hypontremia by serum sodium lowering. Kidney Int 1994, 45:193-200

42. Soupart A, Penninckx R, Stenuit A, Decaux G: Reinduction of hyponatremia improves survival in rats with myelinolysis related neurologic symptoms. I Neuropathol Exp Neurol 1996, 55:594-601.

43. Gankam Kengne F, Soupart A, Pochet R, Brion JP, Decaux G: Re-induction of hyponatremia after rapid overcorrection of hyponatremia reduces mortality in rats. Kidney Int 2009, 76:614-621.

44. Perianayagam A, Sterns RH, Silver SM, Grieff M, Mao R, Hix J, Konides R: DDAVP is effective in preventing and reversing inadevertent overcorrection of hyponatremia. Clin J Am Soc Nephrol 2008, 3:331-336.

45. Soupart A, Decaux G: Efficacy and tolerance of vaptans compared to urea for long-term treatment of patients with SIADH: a prospective study. Acta Clinica Belgica 2009, 64:563, (abstract).

doi:10.1186/cc9292

Cite this article as: Decaux et al:: Treatment of euvolemic hyponatremia in the intensive care unit by urea. Critical Care 2010 14:R184. 